dr., 1993. Professionalnoe samoopredelenie molodezhi: Koncepciya (soobshenie). Pedagogika, 5, s. 33-37.

12. Pryazhnikov, N. S., 1996. Professionalnoe $i$ lichnostnoe samoopredelenie. M.: Izd-vo «Institut prakticheskoj psihologii», Voronezh : NPO «MODEK».

13. Tolgurova, E. E., 2005. Formirovanie predstavlenij o professionalnoj karere $v$ processe zhiznennogo samoopredeleniya starsheklassnika. Kandidat nauk.Severo-Kavkazskij gosudarstvennyj tehnicheskij universitet.

14. Shavir, P.A., 1981. Psihologiya professionalnogo samoopredeleniya $v$ rannej yunosti. M.: Pedagogika.

15. Shapovalov, V.K., 2002. O sootnoshenii ponyatij «karera» i «professionalnaya karera». Psihologicheskij resurs $v$ ekonomike $i$ predprinimatelstve: Materialy Vserossijskoj nauchno-prakticheskoj konferencii. Stavropol: SKSI; Stavropolservisshkola, s. 202-204.

16. Super D. E., 1976. Career Education and the Meanings of Work: Monographs on Career Education. - Washington, DC: U. S. Office of Education.

УДК 377/378:006

https://doi.org/10.32835/2223-5752.2018.16.27-33.

\title{
МЕТОДОЛОГІЧНІ ПІДХОДИ ДО СТАНДАРТИЗАЦІЇ ЗМІСТУ ПРОФЕСІЙНОї ОСВІТИ
}

\author{
Андрій Каленський, \\ доктор педагогічних наук, доцент, \\ завідувач лабораторії науково-методичного супроводу \\ підготовки фахівців у коледжах і технікумах \\ Інститут професійно-технічної освіти НАПН України, \\ ORCID: 0000-0001-9034-5042 \\ e-mail: kaa_1959@ukr.net
}

КлючОВІ СЛОВА:
методологічні підходи:
системний,
діяльнісний,
особистісно-
орієнтований,
компетентнісний,
технологічний,
інформаційний та
культурологічний

Реферат

Представлено результати аналізу публікацій, предметом дослідження яких були питання, тією чи іншою мірою пов'язані 3 методологічними підходами до стандартизації змісту професійної освіти. Обгрунтована нами методологія стандартизації професійної освіти на компетентнісній основі сформована із врахуванням комплексу наукових підходів: системного, діяльнісного, особистісно-орієнтованого, компетентнісного технологічного, інформаційного та культурологічного. Системний підхід дає змогу аналізувати різноманітні чинники впливу на формування змісту стандартизації в їх діалектичному взаємозв'язку. Діяльнісний підхід передбачає спрямованість процесу стандартизації змісту освіти на розвиток ключових i професійних компетентностей майбутніх фахівців та їх практичне застосування для успішної соціальної та професійної самореалізації. Особистісно-орієнтований підхід передбачає врахування в процесі стандартизації змісту освіти потреб і цінностей особистості кожного учасника освітнього процесу. Технологічний підхід сприяє вдосконаленню технології стандартизації змісту професійної освіти 3 урахуванням компетентнісного підходу. Інформаційний підхід означає ефективне використання пізнавального потенціалу інформаційної діяльності, необхідної для формування змісту освітніх стандартів. Культурологічний підхід до стандартизації змісту професійної освіти має три взаємопов'язаних аспекти дії (аксіологічний (ціннісний), технологічний і особистісно-творчий) i дає змогу подолати суперечність між духовним і матеріальним, що існує в сучасному змісті професійної освіти. Компетентнісний підхід покликаний інтегрувати основні положення діяльнісного та особистісного підходів, оскільки полягає в посиленні особистісно-діяльнісного аспекту стандартизації змісту професійної освіти і навчання, передбачає врахування особистісного досвіду майбутніх фахівців, $є$ більш ємним і варіативним, оскільки змістовно визначається ціннісними орієнтаціями особистості.

Постановка проблеми. Модернізація освіти в Україні з метою створення системи професійної освіти i навчання нової якості, здатної задовольнити запити як сучасного українського суспільства, так і економічного сектора країни, не можлива без розробки сучасних інструментів 
вимірювання цієї якості - освітніх стандартів на компетентнісній основі. Проте, навіть існування таких інструментів не гарантує належної якості освіти без: орієнтації освітнього процесу на компетентнісно спрямовані результати, задекларовані в освітньому стандарті; автономного проектування навчальними закладами змісту освіти (навчальних планів, навчальних програм, модулів, зокрема міждисциплінарних, індивідуальних навчальних завдань); досягнення очікуваних результатів навчання засобами адекватних педагогічних технологій; розроблення технологій оцінювання компетентнісних досягнень студентів і випускників та систематичної їх діагностики. Постає питання про сучасні методологічні підходи до стандартизації змісту професійної освіти на компетентнісній основі.

Мета статті полягає в обгрунтуванні методологічних підходів до стандартизації змісту професійної освіти на компетентнісній основі.

Аналіз наукових праць. У роботі проаналізовано публікаціі, предметом дослідження яких були питання, тією чи іншою мірою пов'язані 3 методологічними підходами до стандартизації місту професійної освіти: системного (Ю. Бабанський, В. Беспалько); діяльнісного (Л. Виготський, О. Леонтьєв, С. Рубінштейн); особистісно орієнтованого (I. Бех, О. Дубасенюк, М. Чобітько); компетентнісного (О.Радкевич, R.Bagnall, S.Hodge, P.Hager, R.Wesselink, H.Biemans, J.Gulikers, M.Mulder); технологічного (О.Томашевський, Г.Цегелик, М.Вітер, В. Дубук, В. Курило, Г. Щука); інформаційного (Л. Петренко); культурологічного (I. Буличьов, А. Каленський, Н. Ставська).

Підгрунтям стандартизації професійної освіти на компетентнісній основі є засадничі висновки міжнародних і вітчизняних документів, серед яких: «Ключові навички - 2020», озвучені на 48му Всесвітньому економічному форумі в Давосі у 2018 р.; завдання розвитку сфери професійної освіти і навчання в ЄС до 2020 р., вказані у Брюггському Комюніке 2010 р.; Закон України «Про освіту» (2017).

Виклад

Методологічний рівень науково-дослідної роботи «Методичні основи стандартизації професійної освіти молодших спеціалістів у коледжах і технікумах» грунтується на провідній засаді, що на базі емпіричних i теоретичних досліджень сформулюються методологічні підходи, принципи і методи дослідження даного явища, будується його теорія. Обгрунтована нами методологія стандартизації професійної освіти на компетентнісній основі сформована із врахуванням комплексу наукових підходів: системного, діяльнісного, особистісно-орієнтованого, компетентнісномго технологічного, інформаційного та культурологічного.

Системність - одна 3 ключових характеристик будь-яких явищ та процесів, тому що дає змогу аналізувати різноманітні чинники, які впливають на методичну систему і процес стандартизації. Основні положення системного підходу щодо педагогічних досліджень розглянуті в роботах багатьох учених, ними розроблялися різні варіанти педагогічних систем. Наприклад, Ю. Бабанський (1989) - система навчання; В. Беспалько (1989) - педагогічна система.

Застосування системного підходу в нашому дослідженні даєзмогу:розглянутистандартизацію професійної освіти як цілісну методичну систему; виділити системоутворювальні чинники стандартизації професійної освіти, тобто мету й результат; сконструювати систему стандартизації професійної освіти, виявити ііі складові, розкрити діалектику їх взаємозв’язку; розкрити зумовлені цими складовими внутрішні зв'язки, а також основні умови існування даної системи.

Системний підхід дає змогу аналізувати різноманітні чинники впливу на формування змісту стандартизації в їх діалектичному взаємозв'язку.

Діяльнісний підхід - це теорія, основним положенням якої є положення про провідну роль діяльності в процесі становлення особистості. Розробка загальнопсихологічної теорії діяльності була започаткована ще $\mathrm{y}$ XX ст. такими науковцями як Л. Виготський, О. Леонтьєв та С. Рубінштейн (2000), які зазначали, що лише у процесі діяльності людина створює себе саму. Діяльнісний підхід у стандартизації місту освіти передбачає відбір змісту навчальних предметів 3 опорою на врахування специфіки майбутньої професійної (виробничої) діяльності випускника. Засвоєння знань, умінь, навичок, видів та способів діяльності та відбір змісту освітнього матеріалу має відповідати критерію повноти i системності всіх видів діяльності, необхідних для формування професійної компетентності.

Він передбачає поетапне засвоєння основ педагогічної діяльності і $\epsilon$ оптимальним для 
контролю й організації процесу стандартизації, який визначається, як відомо, не тільки зовнішніми, а й внутрішніми передумовами.

Діяльнісний підхід передбачає спрямованість процесу стандартизації змісту освіти на розвиток ключових i професійних компетентностей майбутніх фахівців та їх практичне застосування для успішної соціальної та професійної самореалізації. Такий підхід - це базова ціннісна орієнтація системи стандартизації загалом i викладача зокрема, визначальна позиція взаємодії суб'єктів у освітньому процесі і процесі стандартизації змісту професійної освіти. Діяльнісний підхід виступає основою нашої методичної системи, конструювання та впровадження якої передбачає проблемність, комплексність впливу на особистість при опорі на знання індивідуальних та вікових особливостей суб'єктів і базується на принципах гуманності, природовідповідності, самовизначення, розвитку, індивідуальної і творчої самореалізації. Цей підхід дає змогу виявити й розкрити специфіку діяльності всіх учасників процесу стандартизації на основі поваги до особистості і довіри до неї, виявити місце й роль суб'єктів у цьому процесі і забезпечувати розкриття й оптимальне використання суб'єктного досвіду.

Особистісно орієнтований підхід у стандартизації змісту професійної освіти базується на розвитку особистості і передбачає передусім визнання іiі пріоритету. Він грунтується працях вчених-педагогів 3 особистісно орієнтованого навчання i виховання (I. Бех, О. Дубасенюк (2012), М. Чобітько (2003).

Особистісно орієнтована освіта

цілеспрямований, планомірний, безперервний, спеціально організований педагогічний процес, спрямований на розвиток і саморозвиток учня, становлення його як особистості з урахуванням індивідуальних особливостей, інтересів, здібностей (Дубасенюк, 2012, с. 16].

Як зауважує М.Чобітько (2003), «в парадигмі особистісно-орієнтованої педагогіки освіта розглядається як багаторівневий простір, як складні процеси, що створюють умови для саморозвитку особистості, який є стрижнем усіх складових освіти (становлення) особистісної індивідуальності. Звідси і нове розуміння освіти - це не просто набуття знань і володіння низкою професійних навичок, а саме розвиток багатогранних здібностей системного характеру і високого ступеня їх продуктивності» (Ставська, 1974).
Особистісно орієнтований підхід до стандартизації місту професійної освіти передбачає встановлення педагогічних закономірностей та світоглядних позицій людини: свободи i вільного вибору свого світосприймання, дій, вчинків, позицій, самовизначення, самостійності і самореалізації, творчості тощо. Зміст особистісно зорієнтованого підходу до стандартизації професійної освіти повинен включати все, що потрібно людині для формування своєї особистості, як професіонала, що здатен до постійного професійного розвитку, самореалізації і самоствердження.

Особистісно-орієнтований підхід передбачає врахування в процесі стандартизації змісту освіти потреб і цінностей особистості кожного учасника освітнього процесу.

Компетентнісний підхід у наукових доробках вітчизняних (В. Андрущенка, О. Дубасенюк, I. Зязюна, В. Кременя, В. Лугового, Н. Ничкало, В. Радкевич, С. Сисоєвої, В. Ягупова) та зарубіжних авторів (R.Bagnall, S.Hodge, P.Hager, R.Wesselink, H.Biemans, J.Gulikers, M.Mulder) i розглядається як методологічна основа професійної освіти. Цей підхід реалізує науковометодологічне забезпечення вимірювань якості освіти, створення науково обгрунтованих засад для стандартизації та оцінювання результатів освіти.

Ми погоджуємося 3 думкою В. Радкевич (2012): «Під компетентнісним підходом необхідно розуміти метод моделювання результатів професійної освіти i навчання та їх представлення у вигляді норм якості підготовки кваліфікованих робітників. Принагідно зауважимо, що компетентнісний підхід не протистоїть традиційному, знаннєвому підходові, який продовжує використовуватися у професійній освіті, а навпаки - істотно розширює його зміст особистісно-орієнтованим навчальним матеріалом».

У зарубіжній літературі зазначено різні очікувані результати впровадження компетентнісного підходу в професійній освіті (Bagnall and Hodge, 2017; Hager, 2017; Wesselink та ін., 2017): покращення відповідності результатів освіти вимогам ринку праці; покращення мотивації студентів до навчання; безперебійні та ефективні процеси працевлаштування абсольвентів освітніх закладів; інтеграція знань, умінь та навиків у процесі навчання, що базується на вимогах виробничих процесів та завдань; орієнтація процесу навчання на результати, які 
не походять 3 процесу навчання та пов'язані 3 продуктивністю діяльності в конкретних робочих місцях; зміна характеру змісту освіти шляхом переходу до змісту, який надає можливості та потенціал для студентів; до нових форм змісту, що дають змогу перейти до гнучкіших програм навчання через модуляризацію; активніша та більш зацікавлена участь підприємств у процесах професійної освіти; збільшення ролі реального робочого місця у процесі навчання наставництво замість шкільної форми навчання; зміна ролі вчителя, викладача зі збілышенням ролі супроводу, дискусії та рефлексії діяльності; індивідуалізація процесів навчання та збільшення ролі й обсягів самостійного навчання.

Компетентнісний підхід покликаний інтегрувати основні положення діяльнісного та особистісного підходів, оскільки полягає в посиленні особистісно-діяльнісного аспекту стандартизації змісту професійної освіти і навчання, передбачає врахування особистісного досвіду майбутніх фахівців, є більш ємним i варіативним, оскільки змістовно визначається ціннісними орієнтаціями особистості.

Технологічний підхід, на думку В. Курила та Г. Щуки (2016), є оптимальним для дослідження складних багатовимірних об'єктів, процесів, явищ. Він являє собою «метод пізнавальної та управлінської діяльності, що дозволяє за допомогою об'єкта-замінника системи адекватно й цілісно відобразити їі сутність, найважливіші якості та засоби».

Цей підхід розглядається як «комплекс наукових та інженерних знань, втілених в способах і засобах праці, наборах матеріальноречових факторів виробництва, видах їх поєднання для створення певного продукту або послуги», а у вузькому - як «набір способів, засобів вибору і здійснення керуючого процесу 3 множини можливих його реалізацій» (Томашевський та ін., 2012). Він передбачає застосування освітніх технологій. Так, Б. Ліхачов трактує поняття «педагогічна технологія» як сукупність психолого-педагогічних установок, які визначають спеціальний вибір і компонування форм, методів, способів, прийомів навчання, виховних.

Технологічний підхід до стандартизації змісту професійної освіти містить мету, функції, засоби, принципи, етапи, процедури й результат стандартизації. Застосування технологічного підходу дозволить розробити технологію стандартизації професійної освіти, що передбачатиме поетапну реалізацію взаємопов'язаних блоківтанаціленанаочікуваний результат. Такий підхід уможливлює розробку різних варіантів реалізації стандартизації, ї коригування 3 метою постійного оновлення та підвищення якості освіти.

Технологічний підхід сприяє вдосконаленню технології стандартизації змісту професійної освіти з урахуванням компетентнісного підходу.

Інформаційний підхід - це сукупність методів наукового пізнання, принципів, умов, які відображають інформаційний аспект дійсності, забезпечується інформатикою та реалізується у процесі інформаційно-аналітичної діяльності (Петренко, 2014, с. 154).

Цей підхід до стандартизації змісту професійної освіти означає ефективне використання пізнавального потенціалу інформаційної діяльності, що розглядаються як сукупність процесів одержання, збирання, аналітико-синтетичної переробки, зберігання, пошуку та розповсюдження інформації, що використовується для створення освітніх стандартів.

В основі інформаційного підходу до стандартизації змісту професійної освіти лежить принцип інформаційності, тобто: інформація $є$ універсальною, фундаментальною категорією; практично всі процеси (в тому числі і стандартизаціï) та явища мають інформаційну основу; інформація є носієм смислу (змісту) всіх процесів, що відбуваються в природі та суспільстві; всі існуючі в природі та суспільстві взаємозв’ язки мають інформаційний характер.

Інформаційний підхід означає ефективне використання пізнавального потенціалу інформаційної діяльності, необхідної для формування змісту освітніх стандартів.

Культурологічний підхід до стандартизації змісту професійної освіти як конкретно-наукова методологія пізнання і перетворення педагогічної реальності має три взаємопов'язаних аспекти дії: аксіологічний (ціннісний), технологічний i особистісно-творчий. Аксіологічний аспект базується на розумінні соціальної природи цінностей, рефлексії смисложиттєвих питань 3 позицій позитивно-творчих цінностей, вплив якісного вибору цінностей на формування ціннісних орієнтирів особистості, на розвиток iii духовного, морального і творчого начал, на ціннісні результати в усіх сферах життєдіяльності. Технологічний - пов'язаний 3 розумінням культури як специфічного способу людської 
діяльності. Саме діяльність є тим, що має загальну форму в культурі. Категорії «культура» $\mathrm{i}$ «діяльність» історично взаємозумовлені. Досить простежити еволюцію людської діяльності, іiі диференціацію та інтеграцію, щоб переконатися в адекватному розвитку культури. Особистіснотворчий - зумовлений об'єктивним зв'язком індивіда і культури. Особа - носій культури. Вона не тільки розвивається на основі об'єктивованої сутності людини (культури), а й вносить до неї щось нове, тобто стає суб' єктом історичної творчості. Культура, у свою чергу, будучи універсальною характеристикою діяльності, наче задає соціально-гуманістичну програму i зумовлює спрямованість того чи іншого виду діяльності, ii ціннісних типологічних особливостей і результатів (Булычёв, 1991; Ставська, 1974).

Культурологічнийпідхід «даєможливістьїхній самореалізації як вільної творчої особистості, здатної успішно діяти в умовах динамічномінливої ситуації, що перебуває у постійному діалозі сама 3 собою, іншими особистостями i творами культури, які втілюють всю попередню і справжню культуру особистості, що здатна брати активну участь у житті суспільства, керуючись такими цінностями, як демократія, повага прав людини тощо» (Каленський, 2014 с. 138).

Культурологічний підхід до стандартизації змісту професійної освіти має три взаємопов'язаних аспекти дії (аксіологічний (ціннісний), технологічний i особистіснотворчий) і дає змогу подолати суперечність між духовним і матеріальним, що існує в сучасному змісті професійної освіти.

Висновки. Таким чином, обгрунтована нами методологія стандартизації змісту професійної освіти на компетентнісній основі сформована iз урахуванням комплексу наукових підходів, а саме: системного, який дає змогу аналізувати різноманітні чинники впливу на формування змісту стандартизації в їх діалектичному взаємозв'язку; діяльнісного - передбачає спрямованість процесу стандартизації змісту освіти на розвиток ключових і професійних компетентностей; особистісно-орієнтованого - враховує в процесі стандартизації змісту освіти потреб і цінностей особистості кожного учасника освітнього процесу; технологічного сприяє вдосконаленню технології стандартизації змісту професійної освіти 3 урахуванням компетентнісного підходу; інформаційного, який означає ефективне використання пізнавального потенціалу інформаційної діяльності; культурологічного - дає змогу подолати суперечність між духовним і матеріальним, що існує в сучасному змісті професійної освіти і компетентнісного, який покликаний інтегрувати основні положення діяльнісного та особистісного підходів, оскільки полягає в посиленні особистісно-діяльнісного аспекту стандартизації змісту професійної освіти і навчання, передбачає врахування особистісного досвіду майбутніх фахівців, є більш ємним і варіативним, оскільки змістовно визначається ціннісними орієнтаціями особистості.

\section{Література}

1. Бабанский, Ю.К., 1989. Избранные педагогические труды. М. : Педагогика.

2. Беспалько, В.П. та Татур, Ю.Г., 1989. Системно-методическое обеспечение учебно-воспитательного процесса подготовки специалистов.М. : Высш. шк.

3. Булычев, И.И., 1991. Человек как интегральная философская проблема: автореф. Доктор наук. Москва.

4. Дубасенюк, О.А., 2012. Професійна педагогічна освіта: особистісно орієнтований niдxiд : монографія. Житомир : Вид-во ЖДУ ім. Івана Франка.

5. Томашевський, О.М., Цегелик, Г.Г., Вітер, М.Б. та Дубук, В.I., 2012. Інформаційні технології та моделювання бізнес-процесів : навч. посіб. К. : ЦУЛ.
6. Каленський, А.А., 2014. Розвиток професійно-педагогічної етики у майбутніх викладачів спеціальних дисциилін: монографія. К.: ЦП «Компринт».

7. Курило, В.С., 2016. Можливості оптимізації науково-дослідної роботи студентів. Освіта та педагогічна наука, 1(164), с. 5-12.

8. Лихачев, Б.Т., 2010. Философия воспитания : спец. курс. М.: Гуманитар. изд. центр ВЛАДОС. - (Педагогическое наследие).

9. Петренко, Л.М., 2014. Теорія $i$ методика розвитку інформаційно-аналітичної компетентності керівників професійнотехнічних навчальних закладів. Доктор наук. Ін-т проф.-техн. освіти НАПН України.

10. Радкевич, В.О., 2012. Компетентнісний підхід до забезпечення якості професійної 
освіти і навчання. В: В.О. Радкевич, ред., Науково-методичне забезпечення професійної освіти і навчання: Звітна науково-практична конферениія. Київ, Україна, 29 Березень 2012. Київ: Інститут професійно-технічної освіти НАПН України.

11. Рубинштейн, С.Л., 2000. Основы общей психологи. СПб.: Издательство «Питер».

12. Ставская,Н.Р., 1974. Философские вопросы развития современной науки : Социологические и методологические проблемы интеграции науки. М. : Высш. шк.

13. Чобітько, М.Г., 2003. Формування особистісно орієнтованої професійної позиції майбутнього вчителя. Неперервна професійна освіта: теорія і практика, 2, с. 155-164.

14. Bagnall, R. \& Hodge, S., 2017. Using an Epistemological Perspective to Understand
Competence-based Vocational and Professional Education. In: M. Mulder (Ed.), Competence-based Vocational and Professional Education.Bridging the Worlds of Work and Education (pp. 125-144). Bern: Springer International Publishing.

15. Hager, P., 2017. The Integrated View on Competence. In: M. Mulder (Ed.), Competencebased Vocational and Professional Education. Bridging the Worlds of Work and Education (pp. 203228). Bern: Springer International Publishing.

16. Wesselink R., Biemans H., Gulikers, J. \& Mulder, M., 2017. Models and Principles for Designing Competence-based Curricula, Teaching, Learning and Assessment. In: M. Mulder (Ed.). Competence-based Vocational and Professional Education. Bridging the Worlds of Work and Education (pp. 533-554). Bern: Springer International Publishing.

\section{KEY WORDS:}

Methodological approaches: systemic, activity, personal-oriented, competence, technological, informational and cultural

\section{Abstract}

Methodological approaches to standardization of professional education content

Andrii Kalenskyi,

Doctor of Pedagogical Sciences, Associate Professor, Head of the Laboratory scientific and methodological support training expertsin universities and colleges Workplace: The Institute of Vocational Education and Training of the NAES of Ukraine,

The results of the analysis of publications, the subject of study of which were questions, are presented in one or another way related to methodological approaches to the standardization of the content of vocational education. The methodology of standardization of professional education, based on our competence, is based on a set of scientific approaches: systemic, activity-oriented, person-oriented, competent technological, informational and culturological. The system approach allows analyzing various factors of influence on the formation of the content of standardization in their dialectical relationship. Activity approach involves the orientation of the process of standardizing the content of education on the development of key and professional competences of future professionals and their practical application for successful social and professional self-realization. Personality-oriented approach involves taking into account in the process of standardizing the content of education needs and values of the individual of each participant in the educational process. The technological approach contributes to the improvement of the technology of standardizing the content of vocational education, taking into account the competence approach. An informational approach means the effective use of the cognitive potential of information activities necessary for the formation of the content of educational standards. The cultural approach to the standardization of the content of vocational education has three interrelated aspects of action (axiological (value), technological and personality-creative) and allows to overcome the contradiction between the spiritual and material that exists in the modern sense of vocational education. Competency approach is intended to integrate the main provisions of the activity and personal approaches, as it consists in strengthening the personality-activity aspect of standardizing the content of vocational education and training, involves taking into account the personal experience of future professionals, is more capacious and variability, since content is determined by the value orientations of the individual.

\section{References}

1. Babanskiy, Yu.K., 1989. Izbrannyie pedagogicheskie trudyi M. : Pedagogika.

2. Bespalko, V.P. ta Tatur, Yu.G., 1989. Sistemno-metodicheskoe obespechenie uchebno- vospitatelnogo protsessa podgotovki spetsialistov. M. : Vyissh. shk.

3. Bulyichev, I.I., 1991. Chelovek kak integralnaya filosofskaya problema: avtoref. 
Doktor nauk. Moskva.

4. Dubaseniuk, O.A., 2012. Profesiina pedahohichna osvita: osobystisno oriientovanyi pidkhid : monohrafiia. Zhytomyr : Vyd-vo ZhDU im. I. Franka.

5. Tomashevskyi, O.M., Tsehelyk, H.H., Viter, M.B. ta Dubuk, V.I., 2012. Informatsiini tekhnolohii ta modeliuvannia biznes-protsesiv : navch. posib. K. : TsUL.

6. Kalenskyi, A.A., 2014. Rozvytok profesiino-pedahohichnoi etyky u maibutnikh vykladachiv spetsialnykh dystsyplin: monohrafiia. K.: TsP «Komprynt».

7. Kurylo, V.S., 2016. Mozhlyvosti optymizatsii naukovo-doslidnoi roboty studentiv. Osvita ta pedahohichna nauka, 1(164), s. 5-12.

8. Lihachev, B.T., 2010. Filosofiya vospitaniya : spets. kurs. M. : Gumanitar. izd. tsentr VLADOS. - (Pedagogicheskoye naslediye).

9. Petrenko, L.M., 2014. Teoriia $i$ metodyka rozvytku informatsiino-analitychnoi kompetentnosti kerivnykiv profesiino-tekhnichnykh navchalnykh zakladiv. Doktor nauk. In-t prof.tekhn. osvity NAPN Ukrainy.

10. Radkevych, V.O., 2012. Kompetentnisnyi pidkhid do zabezpechennia yakosti profesiinoi osvity i navchannia. V: V.O. Radkevych, red., Naukovo-metodychne zabezpechennia profesiinoi osvity $i$ navchannia: Zvitna naukovo-praktychna konferentsiia. Kyiv, Ukraina, 29 Berezen 2012. Kyiv: Instytut profesiino-tekhnichnoi osvity NAPN Ukrainy.

11. Rubinshteyn, S.L., 2000. Osnovyi obschey psihologi. SPb.: Izdatelstvo «Piter».

12. Stavskaya,N.R., 1974. Filosofskie voprosyi razvitiya sovremennoy nauki : Sotsiologicheskie $i$ metodologicheskie problemyi integratsii nauki. M. : Vyissh. shk.

13. Chobitko, M.H., 2003. Formuvannia osobystisno oriientovanoi profesiinoi pozytsii maibutnoho vchytelia. Neperervna profesiina osvita: teoriia i praktyka, 2, s. 155-164.

УДК 377.3-052:629.33/.36]:001.895

https://doi.org/10.32835/2223-5752.2018.16.33-39.

\title{
ТЕОРЕТИЧНІ ОСНОВИ ФОРМУВАННЯ ГОТОВНОСТІ МАЙБУТНІХ КВАЛІФІКОВАНИХ РОБІТНИКІВ АВТОТРАНСПОРТНОЇ ГАЛУЗІ ДО ЗАСТОСУВАННЯ ІННОВАЦІЙНИХ ВИРОБНИЧИХ ТЕХНОЛОГІЙ
}

\author{
Леонід Романов, \\ науковий співробітник лабораторії технологій професійного навчання \\ Інституту професійно-технічної освіти НАПН Украӥни \\ ORCID: 0000-0002-1297-3331 \\ e-mail:leo-volga@ukr.net
}

\section{КЛЮЧОВІ СЛОВА:}

кваліфікований робітник, автотранспортна галузь, готовність,

інноваційні виробничі технології,

заклад професійної (професійно-технічної) освіти
Реферат

У статті актуалізується необхідність науково-методичного супроводу формування готовності майбутніх кваліфікованих робітників автотранспортної галузі до застосування інноваційних виробничих технологій, оскільки успішне оволодіння найсучаснішими виробничими технологіями та їх ефективне використання стає найважливішим завданням підготовки фахівців автотранспортної галузі. Визначено, що існують різні домінанти, навколо яких вибудовуються дидактичні принципи: діяльність (навчальна і професійна), особистість, соціальне партнерство, тому при визначенні принципів формування готовності майбутніх кваліфікованих робітників автотранспортної галузі до застосування інноваційних виробничих технологій доцільним $є$ поєднання особистісних, соціальних і діяльнісних аспектів.

На сьогодні автомобілебудівна промисловість технологічно розвинених країн зорієнтована на новітні технології, що, власне, є одним з найбільших індустріальних інвесторів у наукові дослідження та розробки. Визначено, що успішне оволодіння найсучаснішими виробничими технологіями та їх ефективне використання стає найважливішим завданням підготовки фахівців автотранспортної галузі в закладах професійної (професійно-технічної) освіти.

Встановлено такі принципи формування готовності майбутніх кваліфікованих робітників автотранспортної галузі до застосування інноваційних виробничих технологій: науковості, 